\title{
ICE CORE STUDIES OF WARD HUNT ICE SHELF, I960*
}

\author{
By R. H. Ragle \\ (Arctic Institute of North America, Washington, D.C., U.S.A.) \\ R. G. BLAIR \\ (American Metal Climax, Inc., Climax, Colorado, U.S.A.) \\ and L. E. Persson \\ (Texas Oil Company, New Orleans, Louisiana, U.S.A.)
}

\begin{abstract}
A four-man party representing the Arctic Institute of North America and the Department of Geology, Dartmouth College, went to the Ward Hunt Ice Shelf in I96o to obtain ice cores for subsequent laboratory analysis. The overall objective of the project was to study the structural and stratigraphic history of the shelf and its relationship to the environment through laboratory analysis of the cores, using stratigraphic, petrologic, chemical, and physical methods.

The four cores obtained were logged, packed, and shipped to Dartmouth College for detailed study. The stratigraphy and structure of the ice were studied under natural and plane polarized light conditions. The results of this initial work showed that the cores were composed of four ice types: glacier ice, lake ice, sea ice, and transition ice. Chlorinity, sulfate, and density profiles complemented megascopic studies and were most useful criteria for plotting stratigraphic changes in ice type.

Results of the investigations thus far have yielded new information about the gross structure and stratigraphy of the ice shelf and re-entrant. They have also shown that the physical and chemical techniques employed will be useful in future ice-core analysis.
\end{abstract}

Résumé. Une équipe de 4 hommes appartenant à l"“Arctic Institute of North America" et au "Department of Geology, Dartmouth College", a travaillé sur le Ward Hunt Ice Shelf en rg6o, pour obtenir des carottes destinées à des analyses en laboratoire. L'objectif global de ce projet était d'étudier l'histoire structurale et stratigraphique du shelf et sa relation avec l'environnement, à l'aide d'analyses en laboratoire des carottes utilisant des méthodes stratigraphiques, pétrographiques, chimiques et physiques.

Les 4 carottes obtenues ont été repérées, empaquetées et expédiées par bateau, au "Dartmouth College", pour des études détaillées. La stratigraphie et la structure de la glace ont été étudiées dans des conditions de lumière naturelle et polarisée dans un plan. Les résultats de ce premier travail montrent que les carottes sont composées de 4 types de glace:-glace de glacier - glace de lac-glace de mer-glace de transition. Des profils de densité et de teneur en chlore et sulfate, ont complèté les études mégascopiques et se sont révélés des critères très utiles pour tracer les changements stratigraphiques de types de glace.

Actuellement, les résultats de ces recherches ont fourni de nouvelles informations sur la structure globale et la stratigraphie de l'ice-shelf. Ils ont aussi montré que les techniques physiques et chimiques utilisées seront utiles dans les analyses futures des carottes de glace.

Zusammenfassung. Eine Gruppe von 4 Mitarbeitern des Arctic Institute of North America und der Geologischen Abteilung des Dartmouth Colleges besuchte r960 den Ward Hunt Ice Shelf, um Eiskerne für eine anschliessende Laboratoriumsuntersuchung zu gewinnen. Hauptziel des Unternehmens war das Studium des strukturellen und stratigraphischen Aufbaues des Schelfes und seine Beziehung zur Umgebung durch eine Analyse der Kerne nach stratigraphischen, petrologischen, chemischen und physikalischen Methoden im Laboratorium.

Die 4 Kerne wurden zerschnitten, verpackt und nach Dartmouth College zur genauen Untersuchung versandt. Stratigraphie und Struktur des Eises wurden unter natürlichem und eben polarisiertem Licht studiert. Als Ergebnis dieser Vorarbeit erwies sich die Zusammensetzung der Kerne aus 4 Eisarten: Gletschereis, Seeis, Meereis und Übergangseis. Profile des Chlor- und Schwefelgehaltes sowie der Dichte ergänzten die megaskopischen Studien und lieferten äusserst nützliche Kriterien bei der Ermittlung des stratigraphischen Wechsels der Eisarten.

Die bisherigen Untersuchungen erbrachten neue Erkenntnisse über die Struktur und Stratigraphie des Eisschelfes im grossen. Sie erwiesen weiter die Zweckmässigkeit der angewandten physikalischen und chemischen Methoden für zukünftige Eiskern-Analysen.

\section{INTRODUGTION}

In i96o, an Arctic Institute of North America glaciological program, under the leadership of G. P. Rigsby and H. Lister, was initiated to obtain data that would contribute to an understanding of the characteristics of landward and seaward portions of the Ward Hunt Ice Shelf,

\footnotetext{
* The research reported was conducted under Contracts AF 19(604)-3073 and AF 19(604)-8343 with the Air Force Cambridge Research Laboratories, Office of Aerospace Research.
} 
Ellesmere Island. Accordingly, a four-man drilling team was flown to the shelf by a skiequipped U.S. Air Force C-I 30 Hercules in late April to obtain ice cores for subsequent laboratory study.

\section{Location and description of ice shelf}

The northernmost edge of the Ward Hunt Ice Shelf borders on the Arctic Ocean approximately along the lat. $83^{\circ} \mathrm{I} 2^{\prime} \mathrm{N}$. parallel. The east and west extremes of the shelf are bounded by meridians long. $72^{\circ} \mathrm{oo}^{\prime} \mathrm{W}$. and long. $78^{\circ} 3 \mathrm{o}^{\prime} \mathrm{W}$. respectively. Three mountain ranges

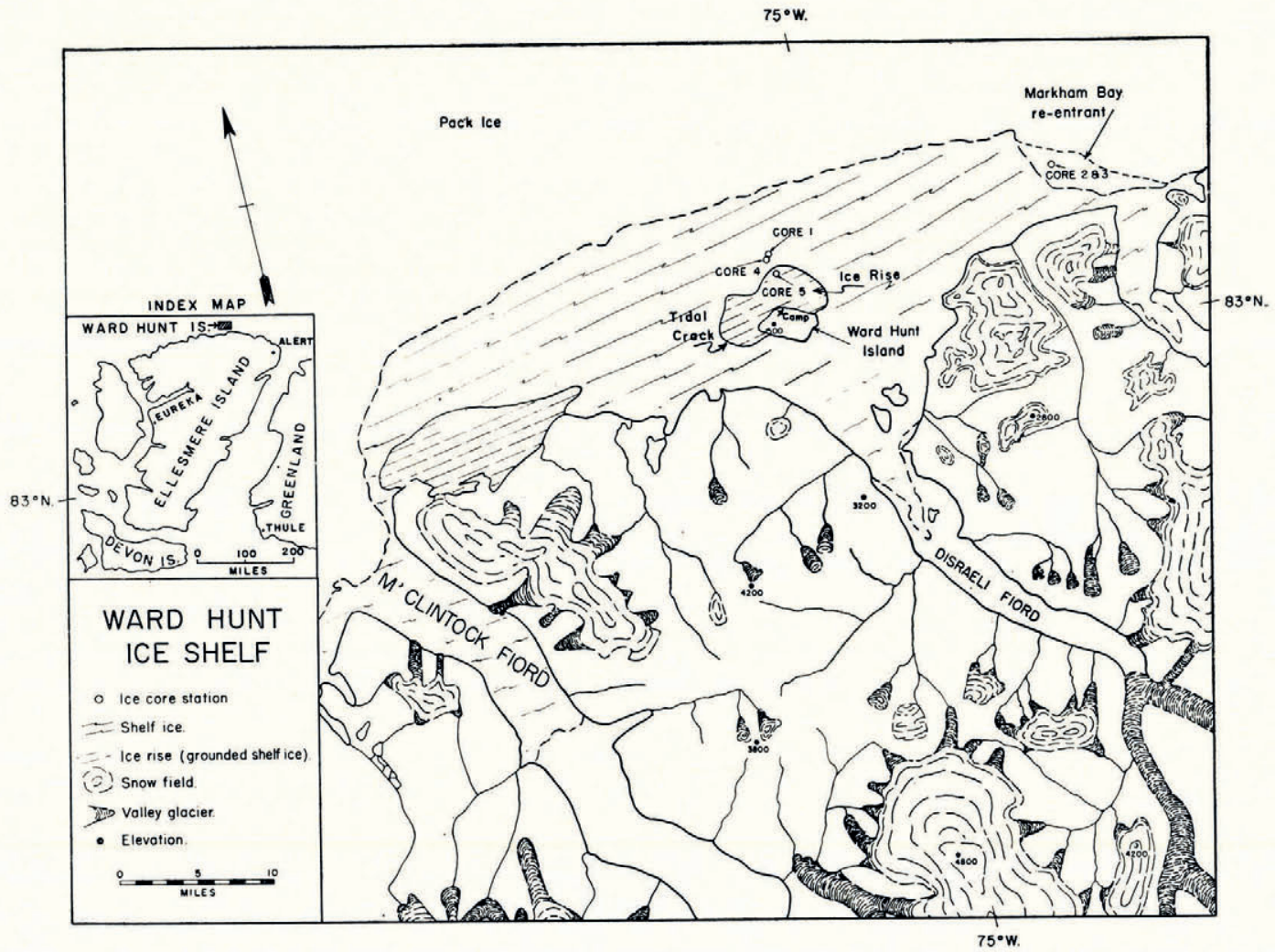

Fig. I. Index map of Ellesmere Island with the Ward Hunt Ice Shelf and locations of ice cores drilled in 1960

with peaks over $3,000 \mathrm{~m}$. high lie to the south in nearly parallel arrangement: the Challenger Mountains, the British Empire Range, and the United States Range, the most formidable of the three. Glaciers from these mountains flow into three bays: Markham Bay at the east end of the shelf; Disraeli Bay in about the center; and M'Clintock Bay at the west end of the shelf (Fig. I). No doubt at one time these glaciers fed the main glaciers which occupied the fiords leading into the bays. This, however, is no longer true for during the height of the summer melt there is open water in the fiords.

The shelf is composed of two parts: the inner, older shelf (south of Ward Hunt Island and up to $7 \mathrm{~km}$. wide) described by Marshall (1955), Crary (1960), and Lyons and Leavitt ( 1961, p. 36), and the outer, younger shelf (north of the Ward Hunt Island and $12-15 \mathrm{~km}$. wide) from which the ice cores were obtained. According to Crary, the older portion of the shelf is probably $\mathrm{I}, 600$ to $3,000 \mathrm{yr}$. old, whereas the younger portion is only $\mathrm{I}, 600 \mathrm{yr}$. old or less. 
Ward Hunt Island lies just outside of Disraeli Bay about $5 \mathrm{~km}$. north of the nearest shore of Ellesmere Island. It is identified by an unnamed hill on the east end of the island and by Walker Hill (500 m. a.s.l.) on the west end. The hills are separated by a saddle occupied in part by a small lake. The main camp of the four-man drilling party was located on the north slope of this island near the shore (Fig. I).

The Ward Hunt Ice Shelf is composed of three primary physiographic features: the floating shelf, the grounded ice rises, $*$ and a re-entrant. $\uparrow$ The single dominating characteristic of the floating shelf is the ridge and trough system running east-west and superimposed upon the sea-ice platform. Equally interesting is the ice rise contiguous to Ward Hunt Island and the Markham Bay re-entrant that is believed to have formed since r 947 (Fig. 2a, b).

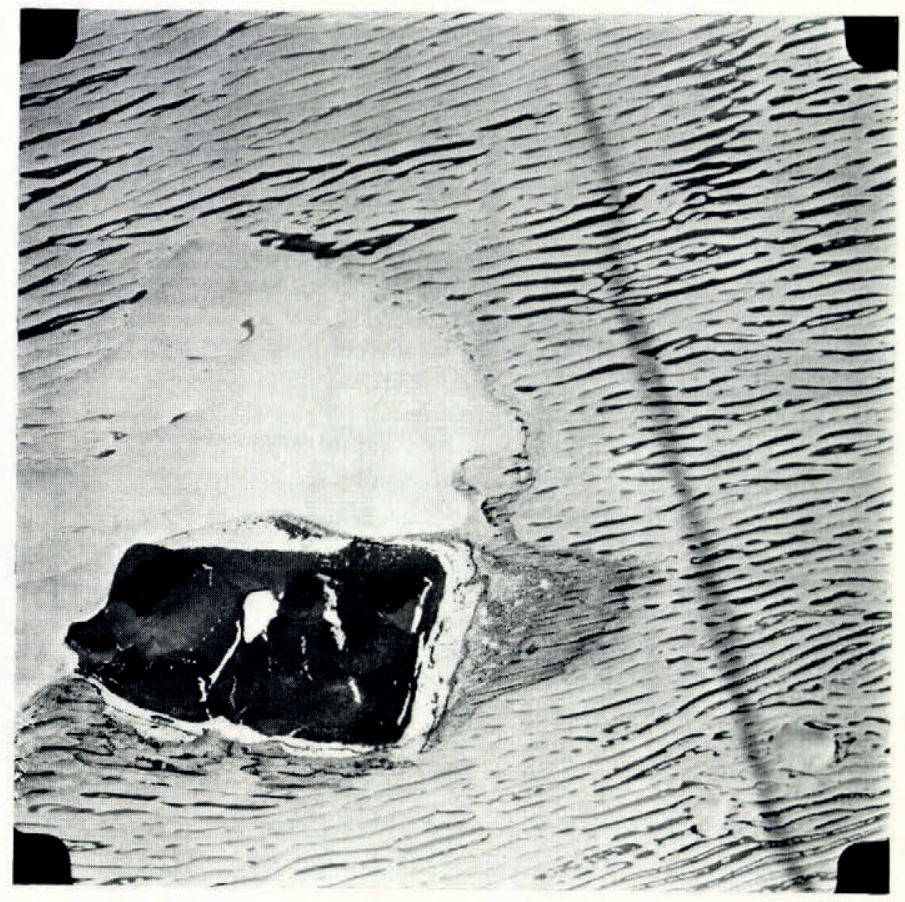

Fig. 2a. Ward Hunt Island and grounded ice rise. Note also the ridge and trough system running generally east-west and the lakes occupying the troughs. Photograph: R.C.A.F. Scale $1: 128$, ooo

\section{Core drilling}

Ice cores were taken from each of the three physiographic features of the ice shelf and thermal profiles from each hole were recorded for study of sub-surface morphology (Lyons and Leavitt, I96I) and thermal history (Lyons and Ragle, I962). Approximately i 30 m. of a core $7.5 \mathrm{~cm}$. in diameter was packed and shipped to Dartmouth College Polar Studies Cold Laboratory in Hanover, New Hampshire, for study.

Hole No. I (Fig. I) was drilled on a ridge and provided about $35 \mathrm{~m}$. of core before slush in the hole threatened freezing in and possible loss of the auger. Seismic records indicate a depth to water of about $4 \mathrm{I} \mathrm{m}$. (Crowley, I96I). Core from hole No. 4, drilled in the trough

* Ice rise: a mass of ice resting on rock and surrounded either by an ice shelf, or partly by an ice shelf and partly by sea and/or ice-free land (Armstrong and Roberts, r956).

$\dagger$ Re-entrant: that portion of the ice shelf which has re-formed and become an integral part of the shelf within the last $15 \mathrm{yr}$. 
immediately north of the ridge hole, yielded $34 \mathrm{~m}$. before slush again prevented further drilling. The third core (Fig. I, No. 5) was taken through the ice rise to a depth of $55 \mathrm{~m}$., where the auger grounded in glacial till. Only the uppermost $36 \mathrm{~m}$. were recovered in time for transport to Dartmouth. The remaining $19 \mathrm{~m}$. were drilled and examined in the field by J. B. Lyons of the Department of Geology, Dartmouth College.

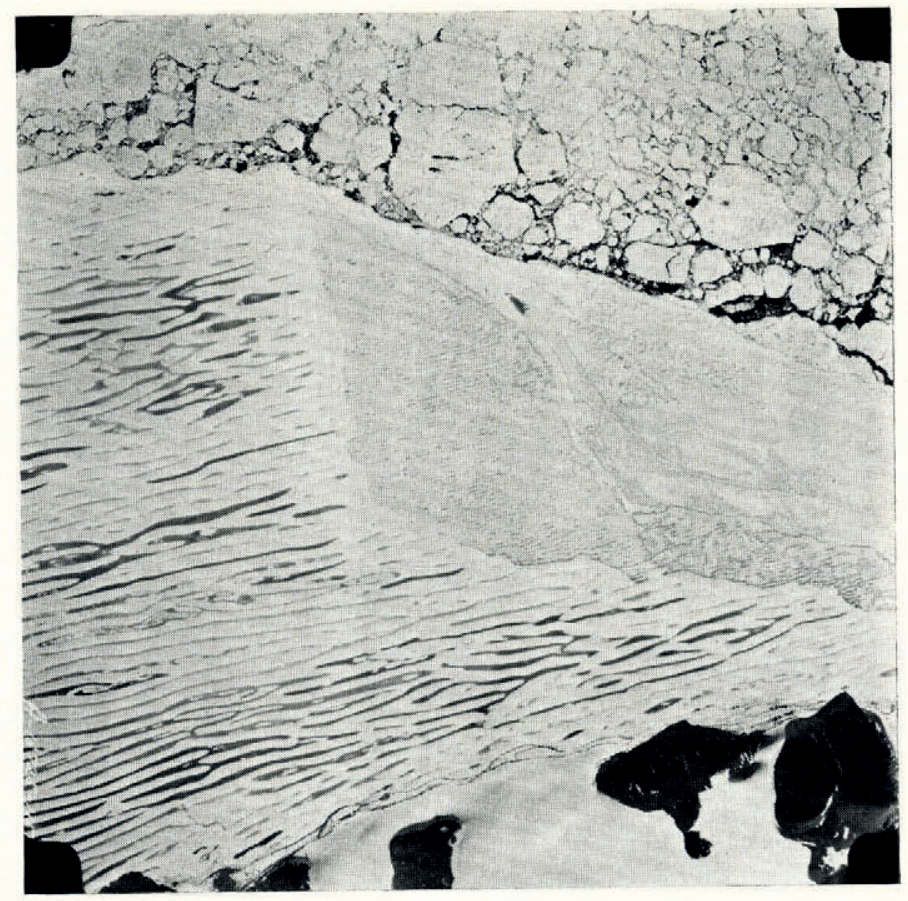

Fig. 2b. Markham Bay re-entrant with ridge and trough system of the ice shelf on the west and pack ice to the north. Photograph: R.C.A.F. Scale $1: 128,000$

Two cores (Fig. I, Nos. 2 and 3) taken from the Markham Bay re-entrant showed it to be about I $\mathrm{m}$. thick and to consist principally of sea ice. The lithologic complexity of this ice suggests that it did not form in place but was more likely a re-entry of rafted and hummocked pack ice which had become fast ice and an integral part of the shelf. This same lithologic complexity is also found in the transition ice at the interface between the easily identifiable glacier ice and sea ice in the cores taken from the ridge, trough, and rise.

Table I. Texture Classification

Size

$\begin{array}{lr}\text { Very coarse } & >3.0 \mathrm{~cm} . \\ \text { Coarse } & \mathrm{I} .5^{-3} .0 \mathrm{~cm} . \\ \text { Medium } & 0.5^{-1} .5 \mathrm{~cm} . \\ \text { Fine } & 0.1-0.5 \mathrm{~cm} . \\ \text { Very fine } & <0.1 \mathrm{~cm} .\end{array}$

\section{Shape}

Granular Crystals more or less equally developed in every direction.

Columnar Crystals better developed in the vertical direction than in the other two.

Tabular Oblate crystals, i.e. crystals better developed in two spatial directions than in the third.

\section{Textures}

The first step in the analysis of the ice cores was a detailed logging of them over natural light to assign quantitative limits to their textures, structures, and sub-structures. 
Four distinct ice types were identified in the cores as a result of the preliminary logging. These are: glacier ice, lake ice, sea ice, and transition ice. The re-entrant core was found to consist of an upper zone of transition ice and the rest sea ice. The other three cores were composed of all four ice types.

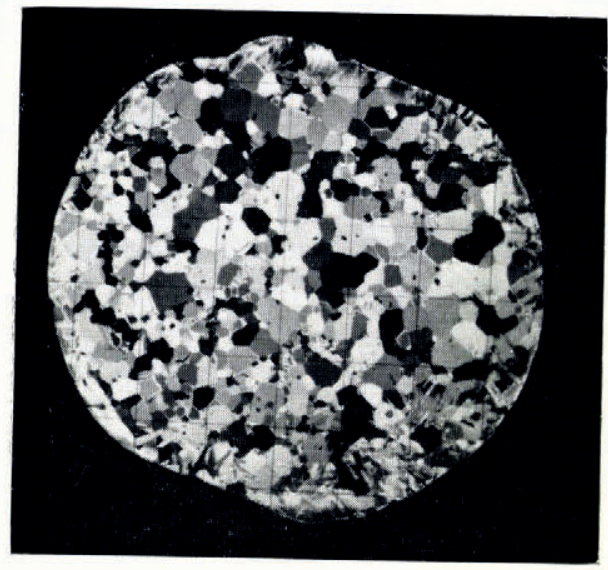

Fig. 3. Horizontal thin section of fine and medium texture glacier ice (trough core; depth $23.96 \mathrm{~m}$.; photographed between crossed polaroids, grid lines are I $\mathrm{cm}$. apart)

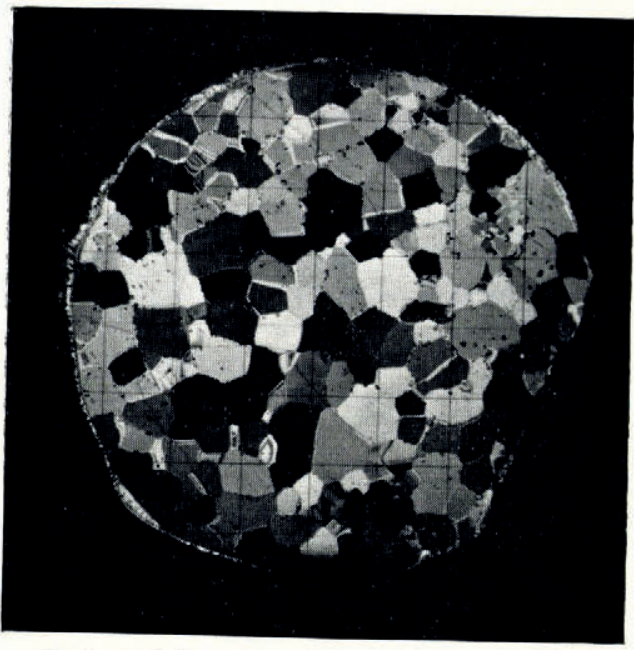

Fig. 4. Horizontal thin section of medium texture glacier ice (trough core; depth $2.03 \mathrm{~m}$.; photographed between crossed polaroids, grid lines are $1 \mathrm{~cm}$. apart)

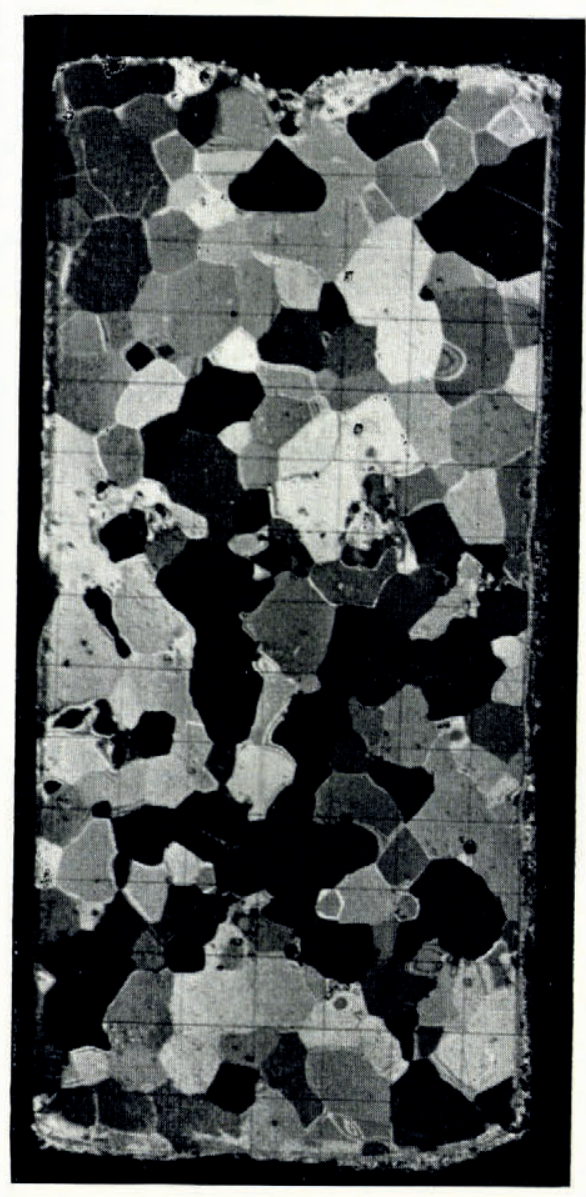

Fig. 5. Vertical thin section of medium and coarse texture glacier ice (trough core; depth $22.28 \mathrm{~m}$.; photographed between crossed polaroids, grid lines are I $\mathrm{cm}$. apart)

The textures observed in the four cores, both in natural and plane polarized light, served as a criterion for distinguishing the different ice types and demonstrated that there is a genetic relationship between texture and ice type. Table $\mathrm{I}$ is a chart listing the grain sizes and shapes used in defining textures. 


\section{Glacier ice}

Glacier ice* is clear to bubbly, somewhat cloudy ice exhibiting a variety of structures and a rather constant texture. Etched by infrared light or viewed in plane polarized light, glacier ice has a homogeneous, medium-grained texture of equant-shaped grains, i.e. euhedral. $\dagger$

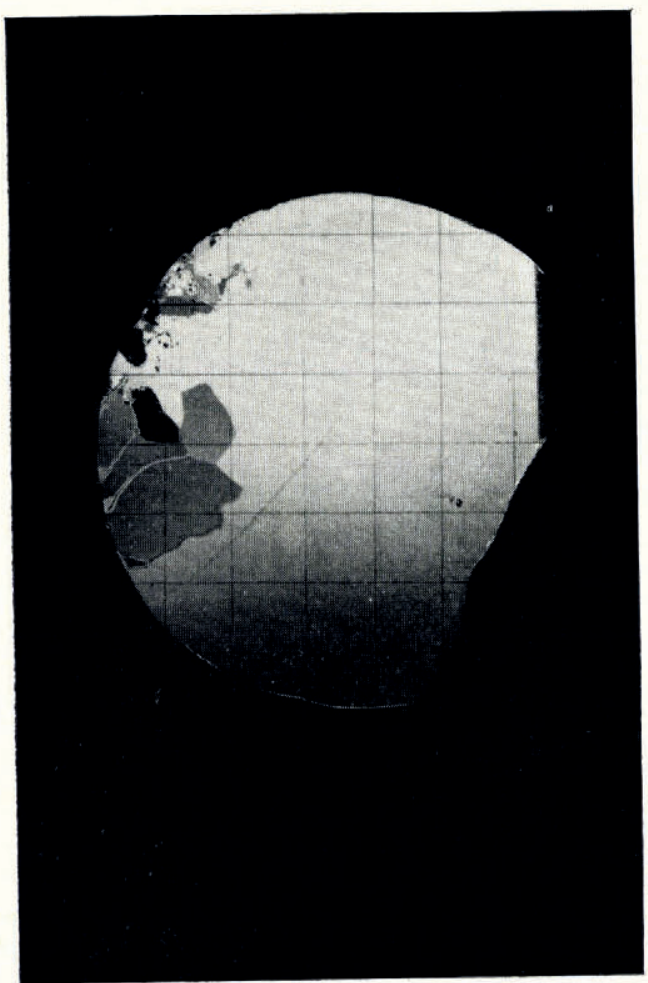

Fig. 6. Horizontal thin section of medium to very coarse texture lake ice (re-entrant core; depth $2.77 \mathrm{~m}$.; photographed between crossed polaroids, grid lines are $1 \mathrm{~cm}$. apart)

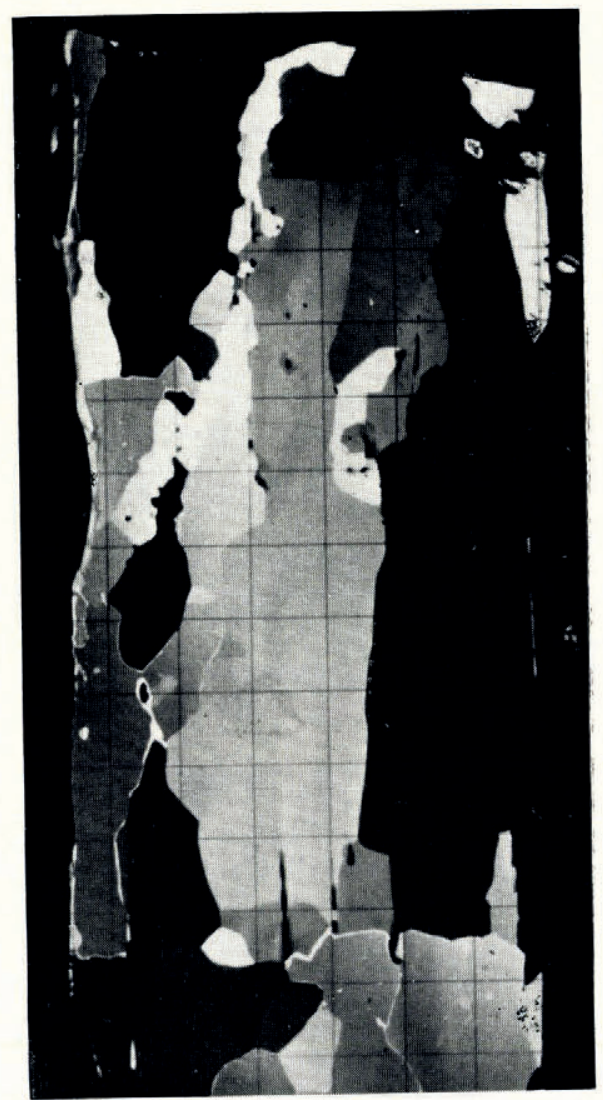

Fig. 7. Vertical thin section of lake ice (trough core; depth IO. $25-10 \cdot 40 \mathrm{~m}$.; photographed between crossed polaroids, grid lines are $\mathrm{I} \mathrm{cm}$. apart)

The criteria for identifying glacier ice were its density, chemistry, generally mediumgrained texture, equidimensional grains in thin section, variable transparency, and large number of bubbles.

The texture of glacier ice is generally medium and granular. Most of the grains are $0.5^{-}$ $\mathrm{I} .5 \mathrm{~cm}$. in size but may range from fine to coarse (Figs. 3, 4, 5). The equidimensional or equant shape is characteristic of this ice type except along a healed fracture or fault where many of the grains become elongated.

* Glacier ice: the term used here does not imply ice which in the genetic process flowed from the land, but ice which is attached to land and, through firnification and densification, has reached a density $>0.83 \mathrm{~g} . / \mathrm{cm} .3$ (Armstrong and Roberts, 1956; Langway, r958).

$\dagger$ Euhedral, subhedral and anhedral are used in the text to describe qualitatively the appearance of the ice crystal boundaries. Euhedral denotes there is a typical mosaic texture, anhedral denotes a very irregular, sutured texture. 
Lake ice

Lake ice on the Ward Hunt Ice Shelf forms in transitory bodies of water which coexist with the ice forming their basins (Lake Type 23c, Hutchinson, 1957); i.e. it forms when summer melt water freezes in troughs of the ridge and trough topography and in puddles or incipient troughs of the re-entrant. It is easily recognized by its medium to very coarse grain texture, the long columnar crystals with straight grain boundaries, and the long, linear, welloriented bubbles which terminate at a boundary defined by $\mathrm{I}-2 \mathrm{~cm}$. of crystal-clear ice (Figs. 6, 7, 1 8, 19, 20). The greatest percentage of columnar grains observed in vertical thin section are larger than $3 \cdot 0 \mathrm{~cm}$.

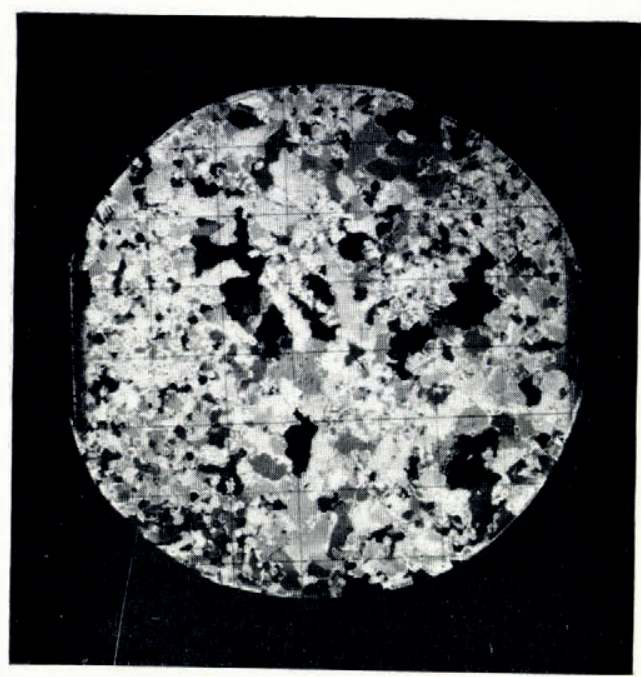

Fig. 8. Horizontal thin section of very fine and fine texture homogeneous sea ice (re-entrant core; depth $9.40 \mathrm{~m}$.; photographed between crossed polaroids, grid lines are $1 \mathrm{~cm}$. apart)

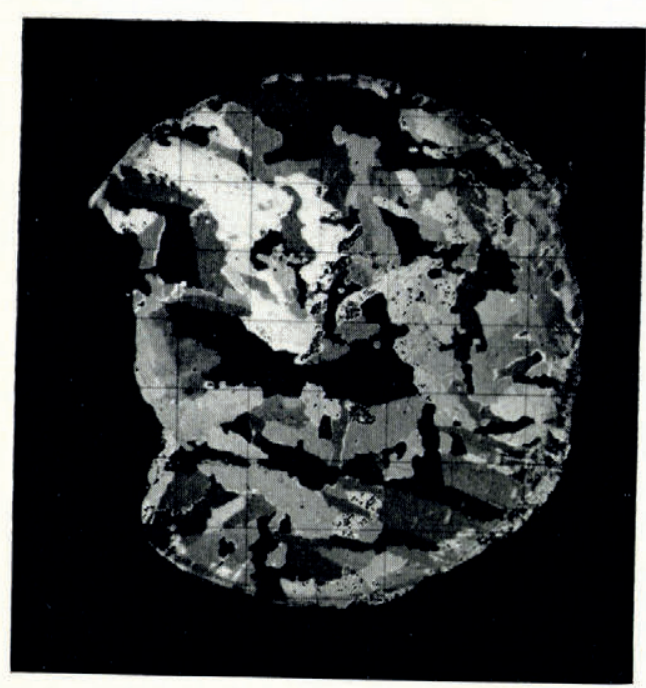

Fig. 9. Horizontal thin section of medium to coarse texture inhomogeneous sea ice (re-entrant core; bottom; photographed between crossed polaroids, grid lines are $1 \mathrm{~cm}$. apart)

In natural light, the lake-ice zones of the core could be determined, but more positive identification was made between crossed polaroids. Research by Lyons and Persson (personal communication) indicates that oxygen analysis can also be used as a reliable parameter in identifying lake ice.

Medium grains form close to or in contact with the air and cold ice along the sides and bottom of the trough. These grains are more granular and tabular than columnar. This same general growth pattern was observed in a temperate lake by Ragle (in press) when a very cold, calm night produced a surface of granular and tabular texture underlain by columnar crystals. Lake ice for the most part is euhedral and subhedral.

Sea ice

Most sea ice viewed in natural light is cloudy and homogeneous. The cloudiness is caused by the presence of very small bubbles, generally less than $500 \mu$; the homogeneity probably results from infrequent fluctuations at the interface of the physical and chemical environment of growing saline crystals. This megascopic characteristic usually was sufficient to distinguish this ice type from other types.

Grain-boundary relationships of old sea ice are distinctly different from those of other ice types. Over natural light, characteristic sutured and irregular grain boundaries became 
evident after a warm iron had been passed over the ice followed by a rapid and light sponging. This interdigitating growth assemblage was composed of a wide range of textures. There were instances where large grains, themselves intergrown, were penetrated and surrounded by medium-grained to very fine-grained crystals. When this type of sea ice, which can be

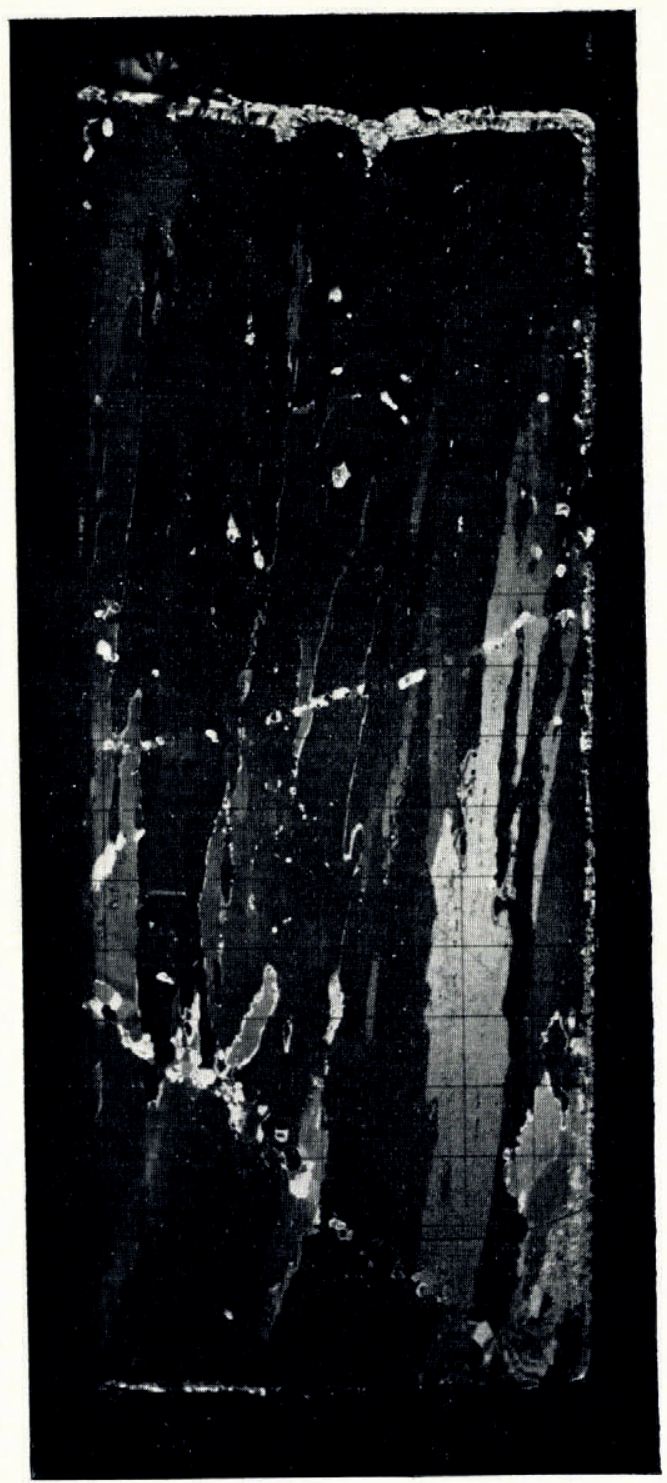

Fig. 1o. Vertical thin section of sea ice showing typical sutured crystal boundaries, brine pockets, and also healed fractures indicated by the two light colored diagonal lines of bubble concentrations (ridge core; depth $27 \cdot 26-27 \cdot 4^{6} \mathrm{~m}$; photographed between crossed polaroids, grid lines are I cm. apart)

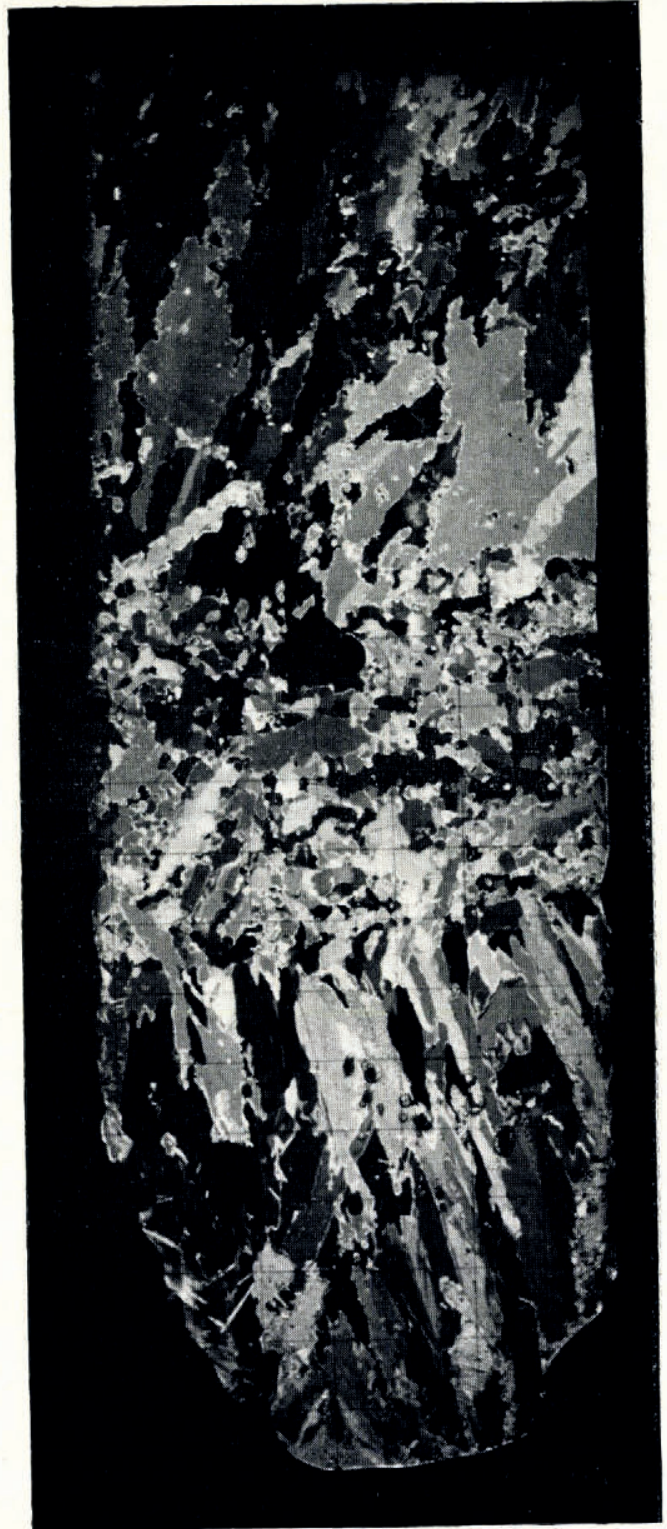

Fig. II. Vertical thin section of the bottom $20 \mathrm{~cm}$. of re-entrant core showing evidence of annual increments of crystal growth (photographed between crossed polaroids, grid lines are $1 \mathrm{~cm}$. apart) 
called "porphyritic", was found, it usually alternated with a homogeneous texture of finegrained, subhedral crystals.

The grain sizes in sea ice range from fine to coarse and the crystals are mostly tabular (Figs. 8, 9, Io). Areas of fine-grained sea-ice crystals up to $0.3 \mathrm{~cm}$. in diameter were fairly homogeneous in texture (Fig. I I), but areas of crystals from $0 \cdot 3-3 \cdot 0 \mathrm{~cm}$. were inhomogeneous in size or shape (Figs. I2, I3). Within their size range, most grains were tabular or columnar with many interesting assemblages of needlelike or thinly tapered crystals. Boundaries are irregular and texture may be said to be anhedral.

The texture of old sea ice is generally coarse and tabular, yet there are zones of granular texture. Both Marshall ( I 955) and Schwarzacher (personal communication) have identified the sequence of granular texture followed by columnar texture to be an annual increment of growth. In Marshall's case, this increment was identified in old sea ice south of Ward Hunt Island. However, Schwarzacher measured and identified this increment in new sea ice forming on the bottom of a floe. Figure i I shows a vertical thin section between crossed polaroids from the bottom $20 \mathrm{~cm}$. of the re-entrant core. Indicated in the photograph is the break between two growth periods, the break occurring approximately $12 \mathrm{~cm}$. from the bottom of the section. Of interest are the much more regular grain boundaries exhibited by the recent coarse-grained crystals in comparison with the irregular boundaries of the older generation of sea ice above. It is possible that the fine-grained ice may represent slush-like saline aggregates which are rafted along the bottom of the sea ice until they become fused to the ice undersurface. Also it may be possible that this fine-grained component is fresh-water ice from melt water flowing under the shelf and freezing (Schwarzacher, 1959; Lyons and Leavitt, I96I). This would explain the abrupt change apparent between the fine and coarse textures. During his studies on Drifting Station A, Schwarzacher (personal communication) found that the break between crystal generations is more commonly identified as a slight dislocation but continuation of former crystal growth. This dislocation can be seen only after etching a

An empirical criterion for identifying sea ice was encountered during the coring operation. A marked increase in the length of unbroken core occurs as soon as the auger penetrates sea ice. Sea ice, because of its greater plasticity, yielded sections of core up to $90 \mathrm{~cm}$. in length; this was in striking contrast to the glacier-ice core which broke by glassy, often conchoidal fractures, and was rarely recovered in pieces longer than $30 \mathrm{~cm}$.

\section{Transition ice}

Transition ice* has the characteristics of the three other ice types and is believed to be the buried former edge of the ice shelf. This ice type was first seen in thin section between crossed polaroids near the anticipated glacier ice-sea ice contact. A zone of mixed typical glacier and sea-ice grains 2 to $3 \mathrm{~m}$. thick and a thin but unmistakable lens of lake-ice type was identified in the ridge, trough, and ice-rise cores. The faulted, chaotic appearance of this ice suggests one of the mechanisms by which the shelf grows.

In the zone of accumulation along the shelf edge, sea-ice floes, blocks, and cakes with a veneer of firn become rafted, fragmented, and disoriented by wind, wave, and tidal forces. The result is a mixture of ice types which, after becoming fast ice, is gradually sandwiched and buried in a landward direction by firn accumulating above and the sea ice accumulating
below.

Evidence to support this thesis (personal communication from Moira Dunbar) was found in the re-entrant cores (Fig. I, Nos. 2 and 3) and strengthened by interpretation of aerial photographs taken by the U.S. Air Force in July 1947, which show that the re-entrant was jammed with much broken-up sea ice quite indistinguishable from the rest of the pack off the

* This ice type is a stratigraphic rock unit or "formation", not a distinct mineralogic assemblage but an
mblage of three other distinct monomineralic units. 
edge of the shelf. There were even small open patches in the area. Trimetrogon photographs taken in $195^{\circ}$ by the Royal Canadian Air Force show the ice to have become unquestionable fast ice and an integral part of the shelf.

The structural history of the Ward Hunt Ice Shelf is an important consideration in accounting for the inhomogeneity of the textures found in transition ice. Ice of every origin so far identified in the structure of the shelf can be identified in the transition ice of each core. Within the section are glacier ice, lake ice, and sea ice as well as zones of brecciated ice which indicates rafting or faulting. This similarity in disorder led to the conclusion that the mechanisms which contributed to the formation of the Markham Bay re-entrant most likely were analogous to those which established the original platform upon which snow was deposited and below which sea ice accreted. An almost "mylonitic" texture can be observed along fractures within this chaotic zone (Fig. I2).
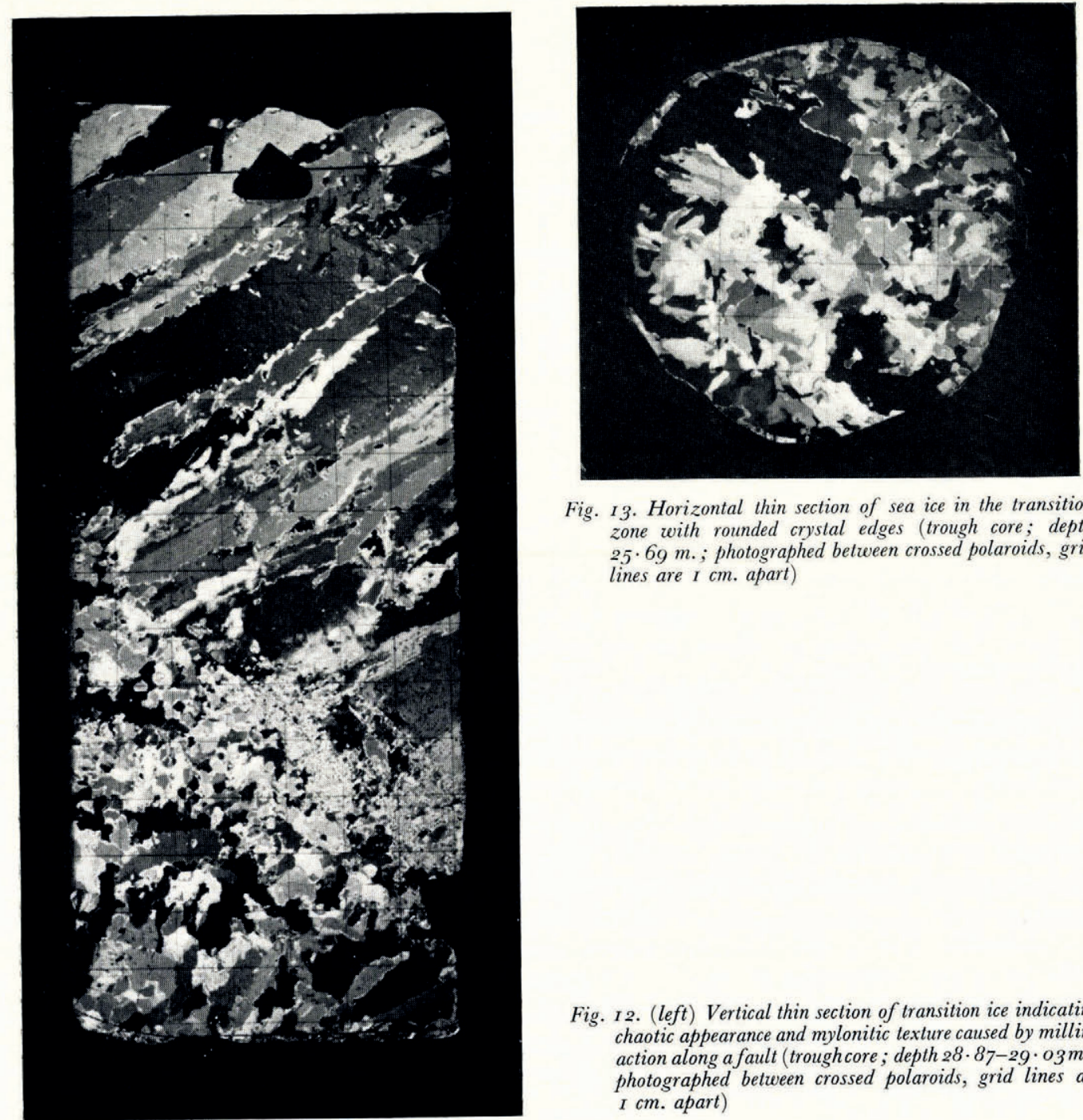

Fig. 13. Horizontal thin section of sea ice in the transition zone with rounded crystal edges (trough core; depth $25.69 \mathrm{~m}$.; photographed between crossed polaroids, grid lines are $1 \mathrm{~cm}$. apart)

Fig. 12. (left) Vertical thin section of transition ice indicating chaotic appearance and mylonitic texture caused by milling action along a fault (trough core; depth $28 \cdot 87-29 \cdot 03 \mathrm{~m}$.; photographed between crossed polaroids, grid lines are I cm. apart) 
In several horizontal and vertical thin sections of transition ice (Figs. I3, I4, I5), the sharp corners and edges of granular, "needle" (tabular) and columnar crystals have been blunted and rounded. A "jigsaw" pattern of interdigitating crystals, each with one or more rounded projections, suggests that brines, migrating through the boundaries of "youthful" ice, melt the crystal edges until enough dilution occurs to allow the brine to freeze at the existing temperature.

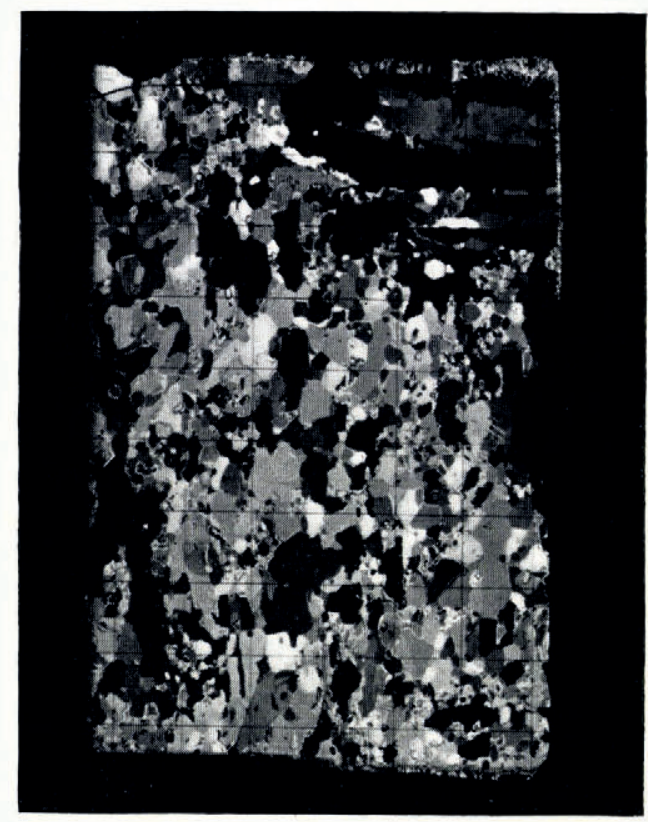

Fig. 14. Vertical thin section of iced firn or glacier ice in transition zone showing a marked rounding of grains (trough core; depth $24.85-24.95 \mathrm{~m}$.; photographed between crossed polaroids, grid lines are $\mathrm{I} \mathrm{cm}$. apart)

Fig. ${ }^{5}$. (right) Vertical thin section of chaotic ice in transition zone showing rounded "needles". Note also the recrystallization along a fracture (trough core; depth $2.5 \cdot 4^{8-}$ $25.63 \mathrm{~m} . ;$ photographed between crossed polaroids, grid lines are $I \mathrm{~cm}$. apart)

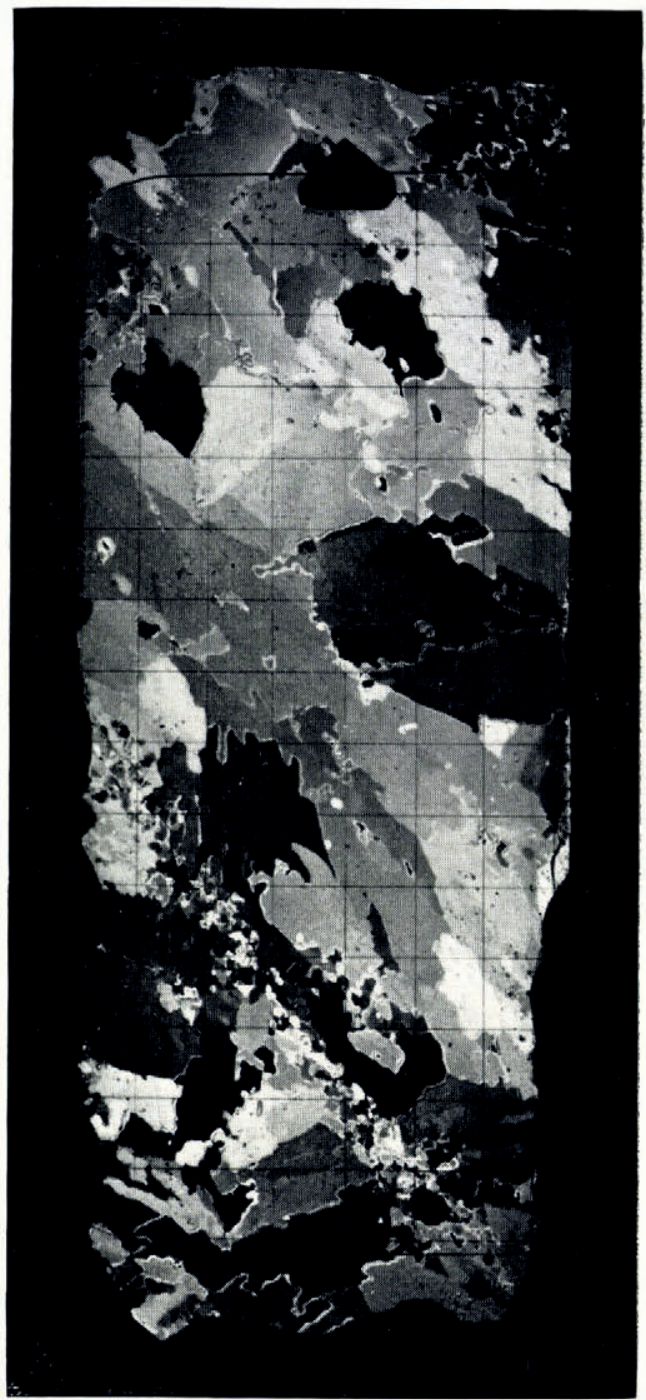

\section{Structure of THE Ice}

Structures within the ice, with emphasis on the interrelationships of these structures, may be regarded as another criterion in the qualitative recognition of ice types from the Ward Hunt Ice Shelf. The structures herein described are fractures and faults, bubbles, dirt layers, brine pockets, vapor figures, and micropolygons. 


\section{Fractures and faults}

Fractures were common in all cores. All of the fractures showed evidence of healing either by the formation of new crystal assemblages (recrystallization) of different textures and orientation than the bordering grains (Fig. I5), or by the planar orientation of sheets of bubbles marking the "ghost" fracture (Figs. I0, I6).

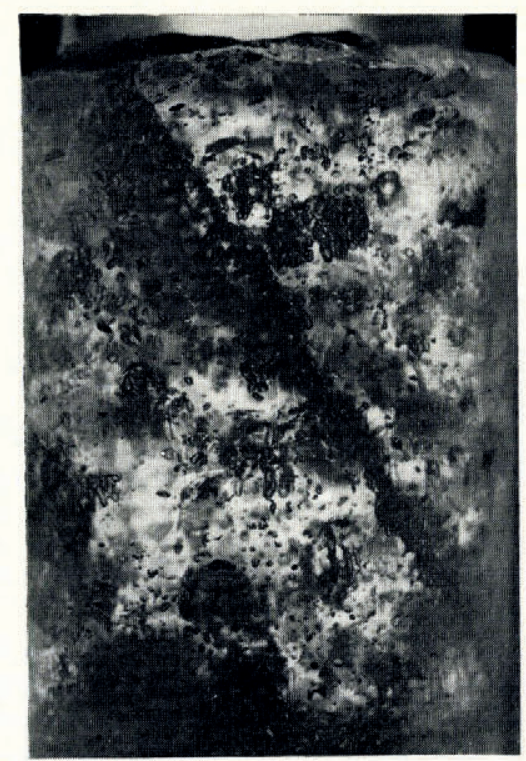

Fig. I6. Bubble plane in lake ice marking a healed fracture (trough core; depth 5.93-6.03 m.)

Fig. 17. (right) Overthrusting (rafting) in re-entrant core (depth $I \cdot 73^{-I} \cdot 84 \mathrm{~m} . ;$ photographed between crossed polaroids, grid lines are $1 \mathrm{~cm}$. apart)

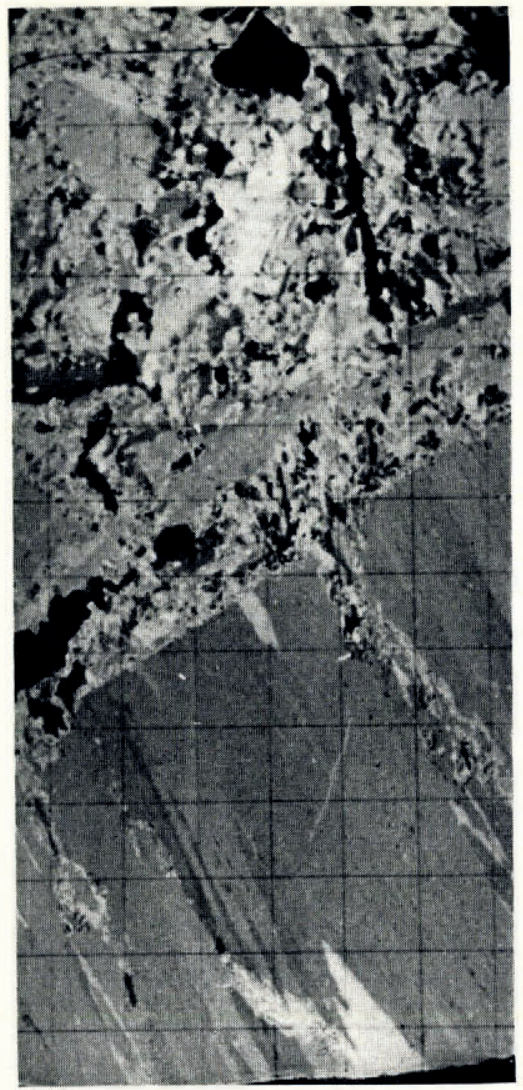

It was observed in the field that overthrusting (rafting) of ice was clearly active at the edge of the shelf. Thin sections from the Markham Bay re-entrant core showed repeated truncation of crystals by obliquely oriented overlying crystals (Figs. I 2, I 7). In $34.94 \mathrm{~m}$. of trough core (Fig. I, No. 4), one normal fault was logged with a displacement of approximately I $\mathrm{cm}$. The ridge core (Fig. I, No. I) also exhibited one normal fault of about $\mathrm{I} \cdot 5 \mathrm{~cm}$. displacement. Both faults occurred in glacier ice, the former at a depth of $4 \mathrm{~m}$., the latter at a depth of $18 \mathrm{~m}$. Most of the fractures and both faults were subvertical; very few of the fractures had a dip less than 45 degrees.

\section{Bubbles}

Bubbles constitute the most common structure in the cores. Theoretically their shape, composition, pressure and frequency should be distinct in all ice types and genetically related to the ice in which they occur, as wcll as having a quantitative relationship with the strength properties of ice. The size of the bubbles ranged from microscopic in glacier and sea ice to more than $10 \mathrm{~cm}$. long in lake ice. The most frequent shape in glacier ice was approximately 

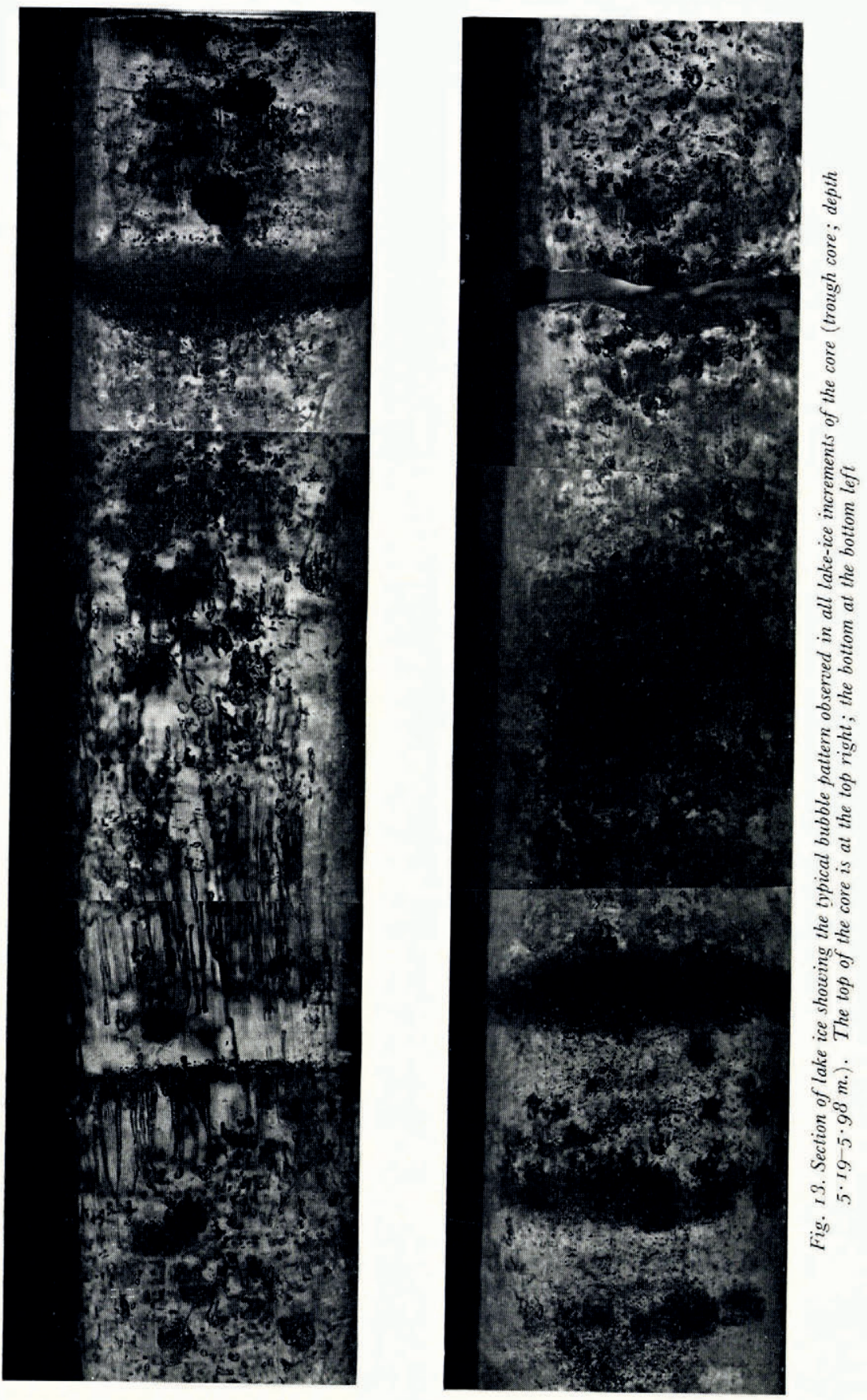
spherical, and in sea ice predominantly teardrop. In general, sea-ice bubbles were smaller and more numerous than those in glacier or lake ice, although long tubular bubbles similar to those in non-saline ice do occur. The cloudy appearance of much of the sea ice is consistent with the abundance of microscopic bubbles.

The occurrence of bubble clusters was nearly as common as that of single bubbles not in a cluster. Their shapes ranged from spherical to subspherical, and, as in the case of individual bubbles, clusters gave evidence of migration. Glacier ice contained more bubble clusters than lake ice, although lake ice exhibited many clusters in ice nearest to the freezing surfaces. Figure 18 is a section taken from the trough core. The break in the core is $5.6 \mathrm{~m}$. below the

Fig. I9. Long tubular bubbles terminating where last liquid water freezes in formation of lake ice. Note vapor figures (inclined disks) at top of photograph (trough core; depth $10 \cdot 80-10 \cdot 94 \mathrm{~m}$.)

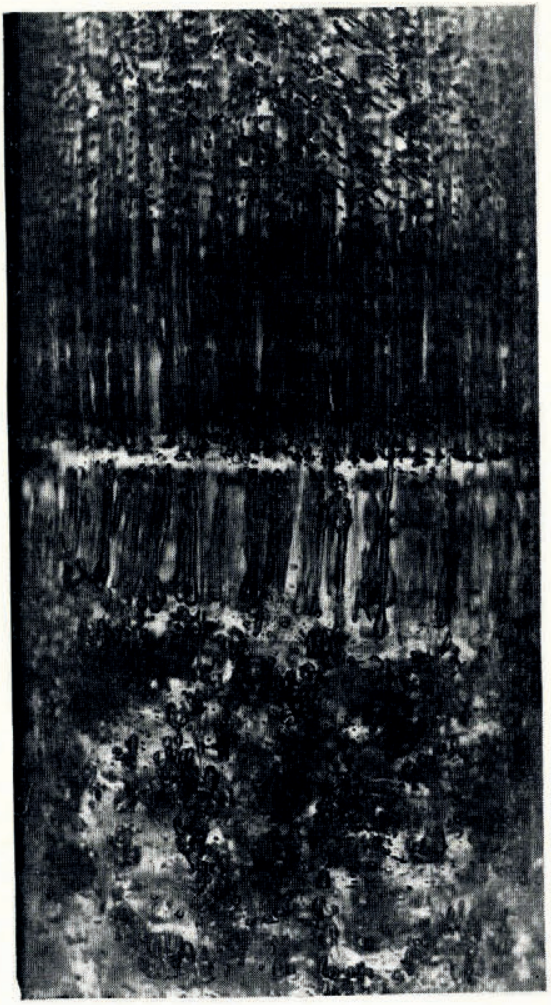

present surface of the shelf. The photograph, taken in natural light, illustrates a typical pattern of lake-ice origin. At both ends of the section there are bubble clusters, which show evidence of migration, and dense lenticular bubble layers. These regions are followed by a confused zone of bubbles of many shapes and sizes displaying no apparent order or orientation. Finally, as a band of clear ice is approached, the bubbles become fistular and in most cases terminate abruptly at both top and bottom (Fig. 19).

This clear band is believed to be the last liquid water to freeze. This opinion is substantiated by the following observation. During late September and October I 959, personnel from the U.S. Naval Civil Engineering Laboratory formed an ice pad on a ridge by successive floodings of a confined area. The water froze quickly as a result of rapid loss of heat to the atmosphere and to the cold reserve of the solid base. The temperature of the water at the source was $+\mathrm{r}^{\circ} \mathrm{C}$., and at the discharge end of the hose the temperature was $\mathrm{o}^{\circ} \mathrm{C}$. At night 
temperatures fell well below $-18^{\circ} \mathrm{C}$., reaching a minimum of $-46^{\circ} \mathrm{C}$. on 2 I October 1959 . A core taken from this pad showed that the rapid cooling of the water mass from the top and bottom produced ice identical to increments found in the ridge, trough, and rise cores. Figure 20 is a sketch of a section of the core taken from the pad.

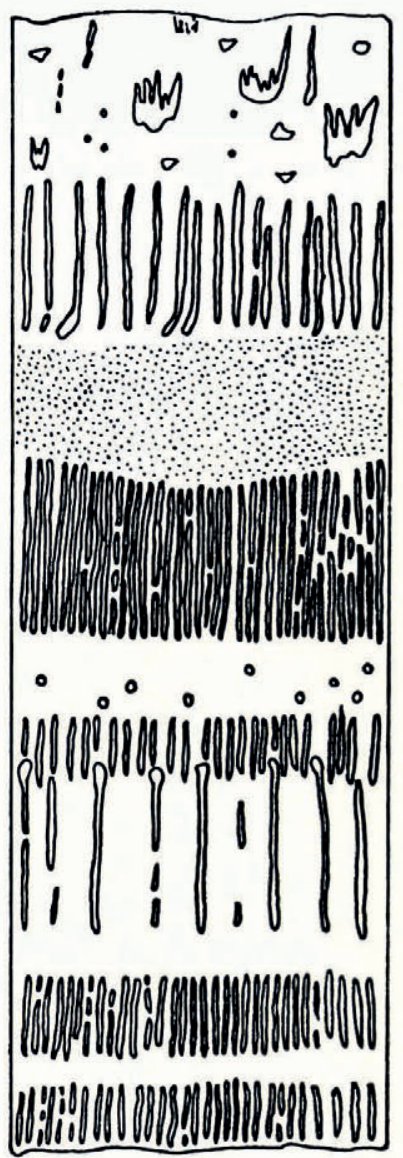

Fig. 20. Sketch of core through a man-made lake. Note migrating bubble clusters and similarities to Figures 18 and 19

\section{Dirt layers}

Dirt layers were recognized in the ridge, trough and ice-rise cores. Except for a notable concentration in frequency and density in or immediately adjacent to the transition zone, the distribution and densities of the layers are quite constant. Generally the layers are spread over $\mathrm{I}-4 \mathrm{~cm}$. of core. Up to the present time no stratigraphic correlations have been recognized between cores. A high density dirt layer also was noted on or just below the i 960 summer surface.

\section{Brine pockets}

Brine pockets are found in the sea ice from all four cores. The best developed, however, are found in the youngest ice, ice from the re-entrant core (Fig. 21, 22). In all cores the pockets or layers of brine are from $0.3-0.8 \mathrm{~mm}$. in thickness separating planes of more pure ice $0.8-\mathrm{r} .5 \mathrm{~mm}$. thick. The maximum values in both cases appear to be confined to the re-entrant ice. 


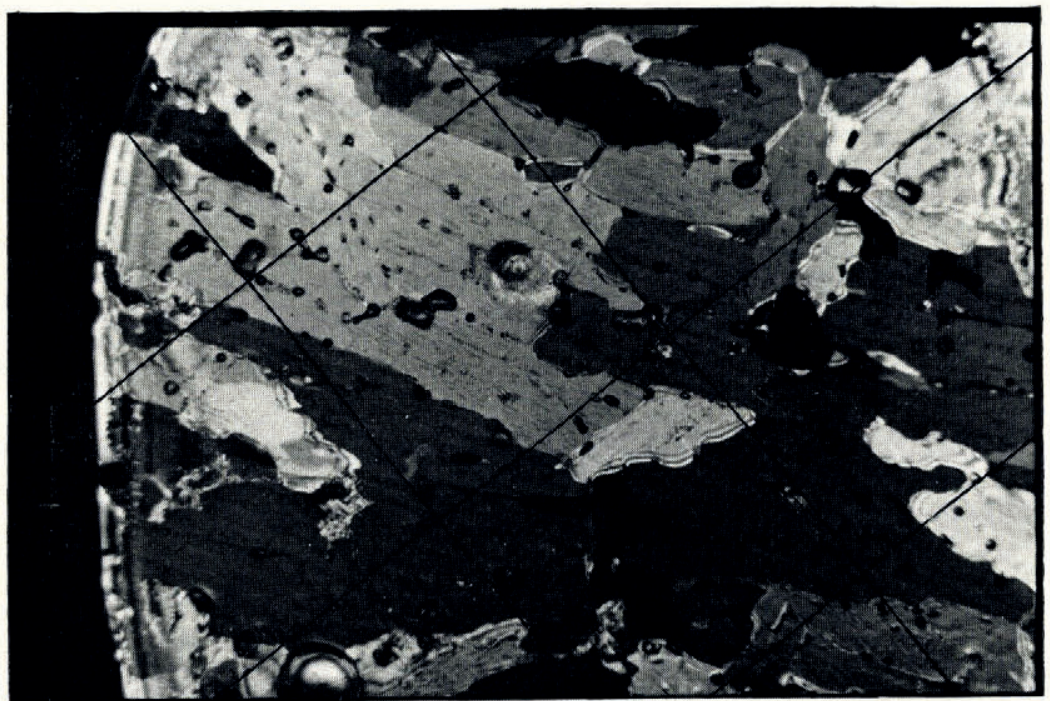

Fig. 2I. Horizontal section. Cross-section of new sea ice in re-entrant core showing brine pockets (grid lines are I cm. apart)

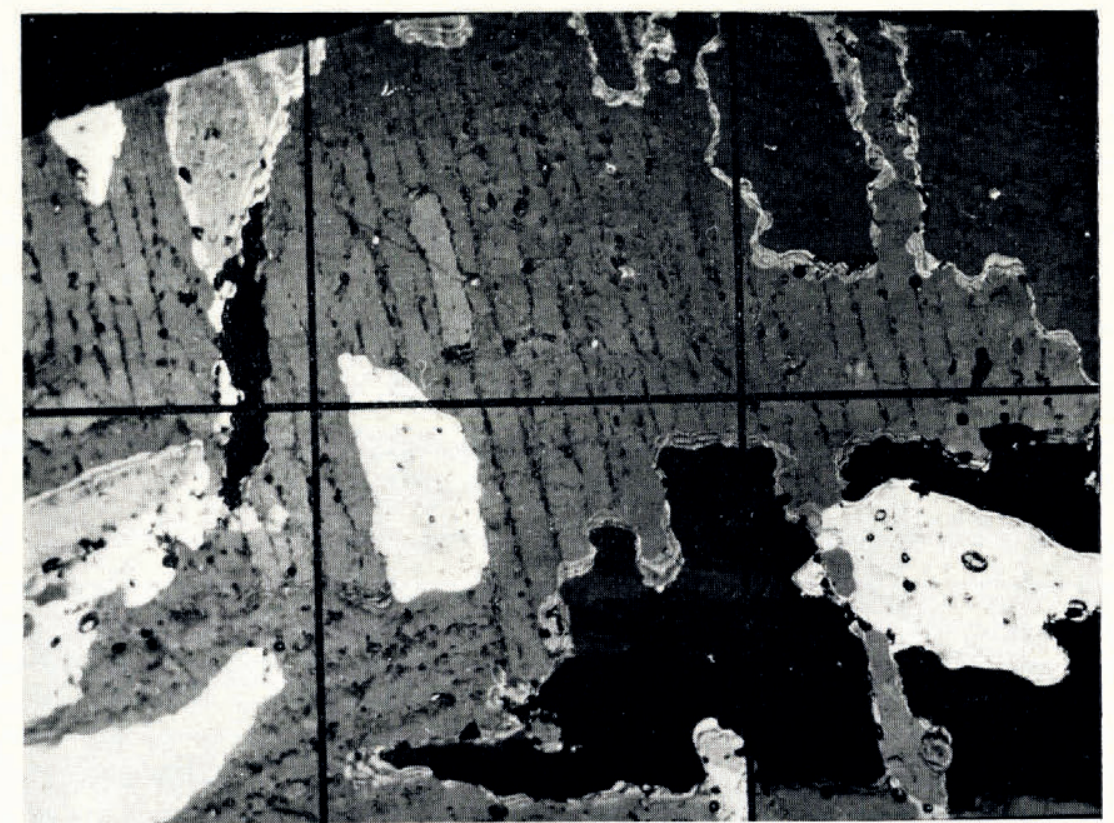

Fig. 22. Horizontal section. Cross-section of re-entrant core about $2 \mathrm{~m}$. from top showing well-developed brine pockets ( $\mathrm{grid}$ lines are $1 \mathrm{~cm}$. apart)

Vapor figures

Vapor-figure concentrations occur with great frequency and varying density in all the glacier ice above the transition zone in the ridge, trough and ice rise cores (Fig. I9). An extensive visual examination of vapor figures in the trough core showed no correlation between 
the frequency, position, and density of vapor figure zones and other structural features. Orientation was noted but no fabric pattern evolved since there were as many horizontal figures (vertical $c$-axes) as those inclined to either side of the horizontal. Evidence of migration is present and indicates that most movement was upward.

\section{Micropolygons}

Micropolygonal figures on the order of $0.5 \mathrm{~mm}$. in their largest dimension were observed in sea ice using a compound microscope with a high-powered objective. They were usually

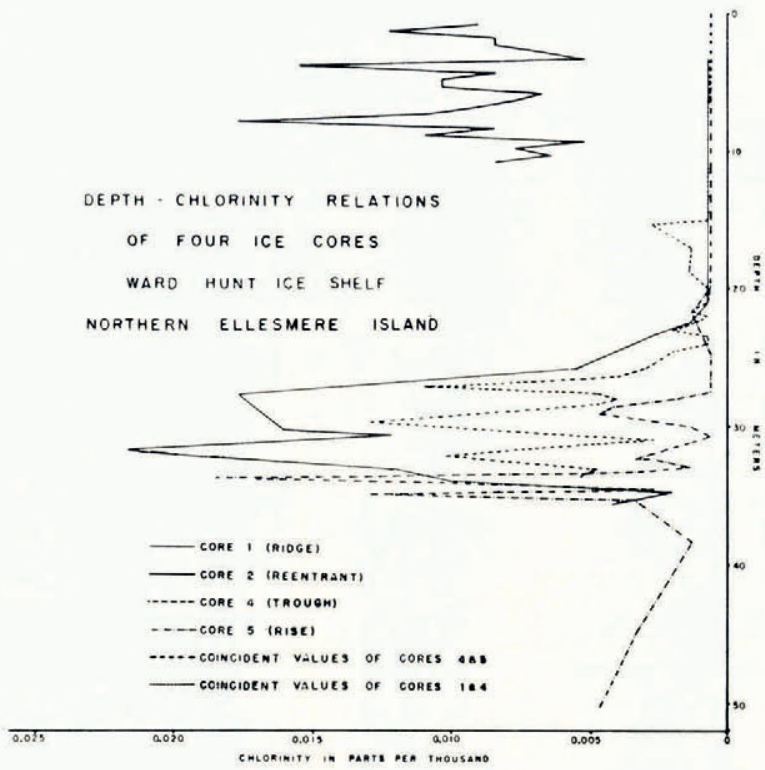

Fig. 23. Depth - chlorinity relations of four ice cores, Ward Hunt Ice Shelf, northern Ellesmere Island

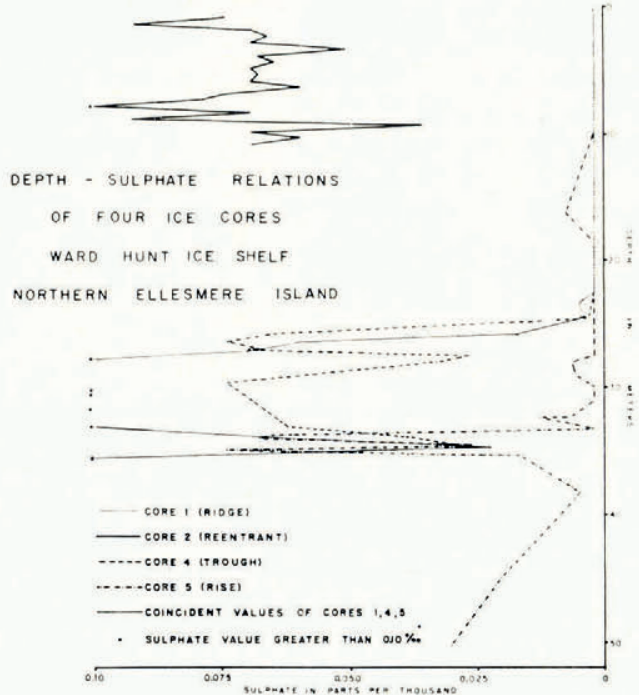

Fig. 24. Depth - sulphate relations of four ice cores, Ward Hunt Ice Shelf, northern Ellesmere Island 
hexagonal in shape but also occurred as 4 - and 6-sided polygons. These features are similar to the strain figures which precede subboundary formation described by Knight (1962) as associated with internal stresses. It is also possible that they are relic features resulting from a temperature flux.

\section{Chemistry and Physics}

\section{Chlorine and sulphate}

Chlorine and sulphate analyses were made on the cores to obtain quantitative information on the amount of these salts in the different ice types. These data helped define another

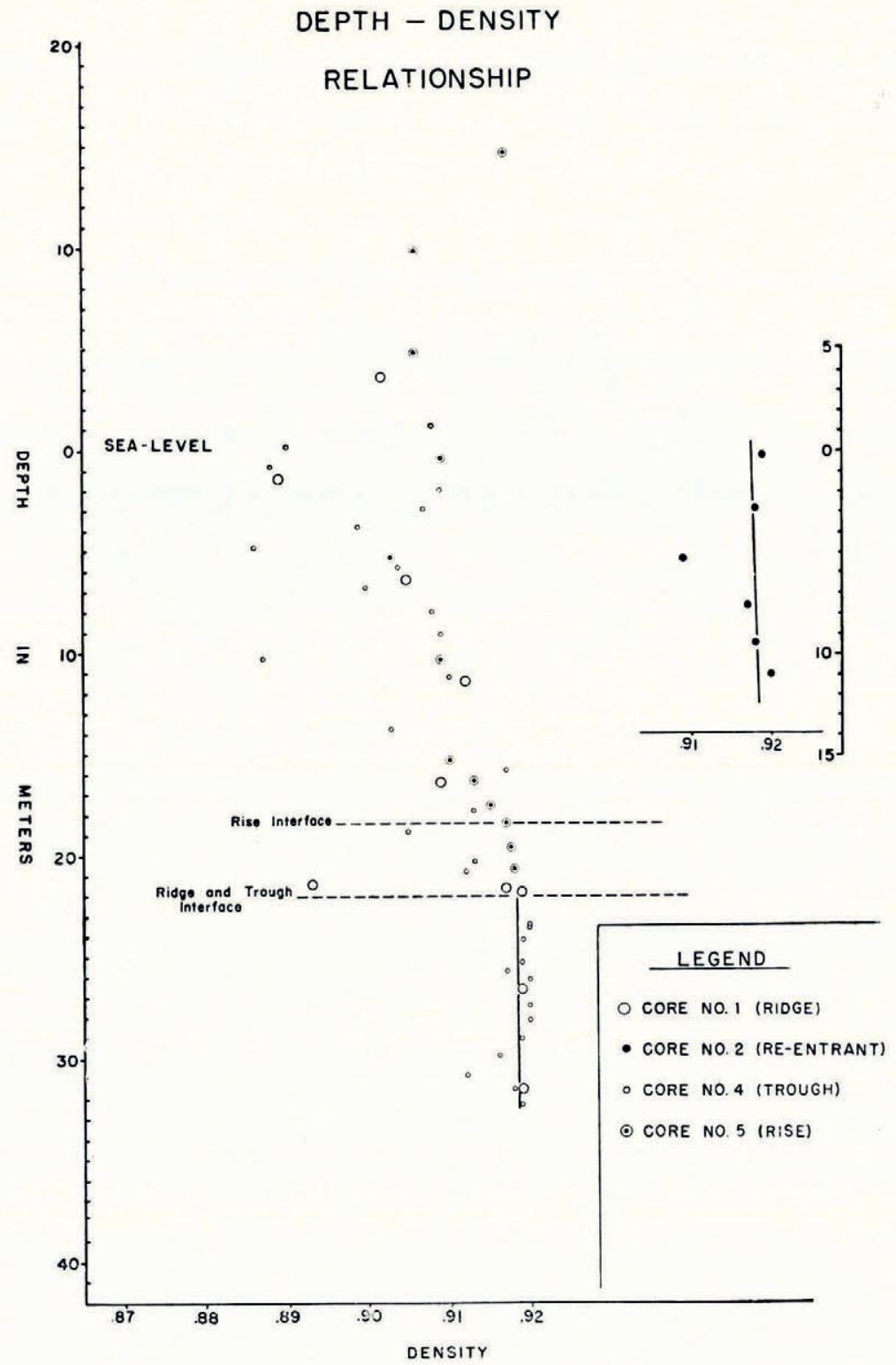

Fig. 25. Depth-density relationship 
parameter for the positive identification of a transition zone or interface between easily identifiable glacier and sea ice.

The chlorine ion concentration of the core samples was measured by a standard titration method with silver nitrate. Potassium chromate was used as the indicator, and standard seawater from Denmark $\left(\mathrm{Cl}^{-}, \mathrm{I}_{3} \cdot 970 \%\right.$ ) was the standard against which the titrations were performed.

Sulphate ion analyses were computed by the turbidimetric method (American Health Association, Inc., 1960) which involves the precipitation of the sulphate ions as barium sulphate followed by a colorimetric measurement of the ion concentration.

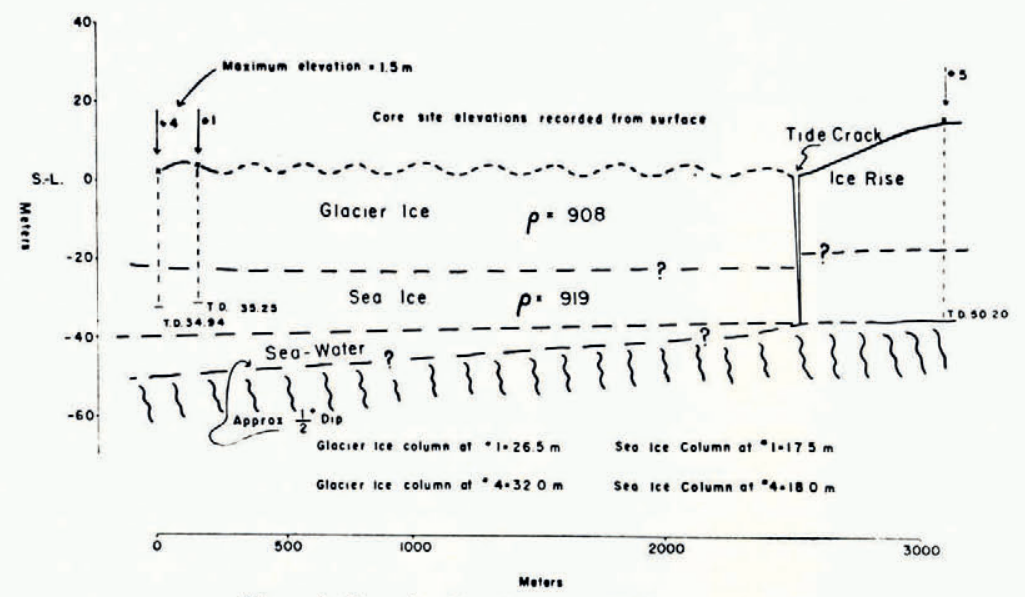

Fig. 26. Core site elevations recorded from surface

No background salts were detectable in the de-ionized water used for dilution in both $\mathrm{Cl}^{-}$and $\mathrm{SO}_{4}^{--}$determination. The limits of detectability for the chlorine and sulphate are $0.06 \%$ and $0.002 \%$ respectively. Standard deviations were calculated from four groups of data and are as follows: chlorine in glacier ice $0 \cdot 026 \%$; chlorine in sea ice $0 \cdot 060 \%$; sulphate in glacier ice $0 \cdot 060 \%$; sulphate in sea ice $0 \cdot 163 \%$.

The results of these chemical analyses show that the glacier ice-sea ice interface, even in very old sea ice, can be detected easily. In Figures 23 and 24 it can be seen that there is little difference between the brine content of the two older cores and the younger re-entrant core. The rise core, in comparison, shows a low brine content, indicating that brine within the seaice member of the grounded ice rise either has continued to drain from the bottom because of less proximity to the sea-water or that it is a remnant of a shelf older than the floating shelf of present day and has had a longer time for the brine to drain. The re-entrant, though a recent addition to the shelf, would not be expected to differ from the older floating ice because rapid loss of brine occurs in the first year after the initial freeze followed by a much less rapid drainage (leakage) (Weeks and Lee, i962).

\section{Densily}

In the field, ice densities were computed from measurements of weight and volume. In order to be more certain of the third-place figure, however, the immersion method for calculating densities of solids was employed in the laboratory, using 2,2,4-trimethylpentane at a controlled temperature.

The spread of values of eight samples processed two or more times was $0 \cdot 002 \mathrm{~g} . / \mathrm{cm} .{ }^{3}$.

Figure 25 is a plot of the depth-density data. The zero datum is present sea-level and the position of the glacier ice-sea ice interface is marked. A least-squares analysis shows no 
significant correlation between density and depth in either the glacier or sea ice portions of the plot. However, there is a significant difference in density between the two ice types. The glacier ice also shows a larger scatter in the density values and perhaps a slight correlation between the modal density at a given level and the depth.

The plot and Figure 26 also show that the interface in the rise core is above the level at which it occurs in the ridge and trough. It is conceivable that the difference may be a measure of post-glacial isostatic rebound, for sudden uplift of this magnitude perhaps could explain the unpredicted break-off of the shelf which has occurred since the ig6o field season.

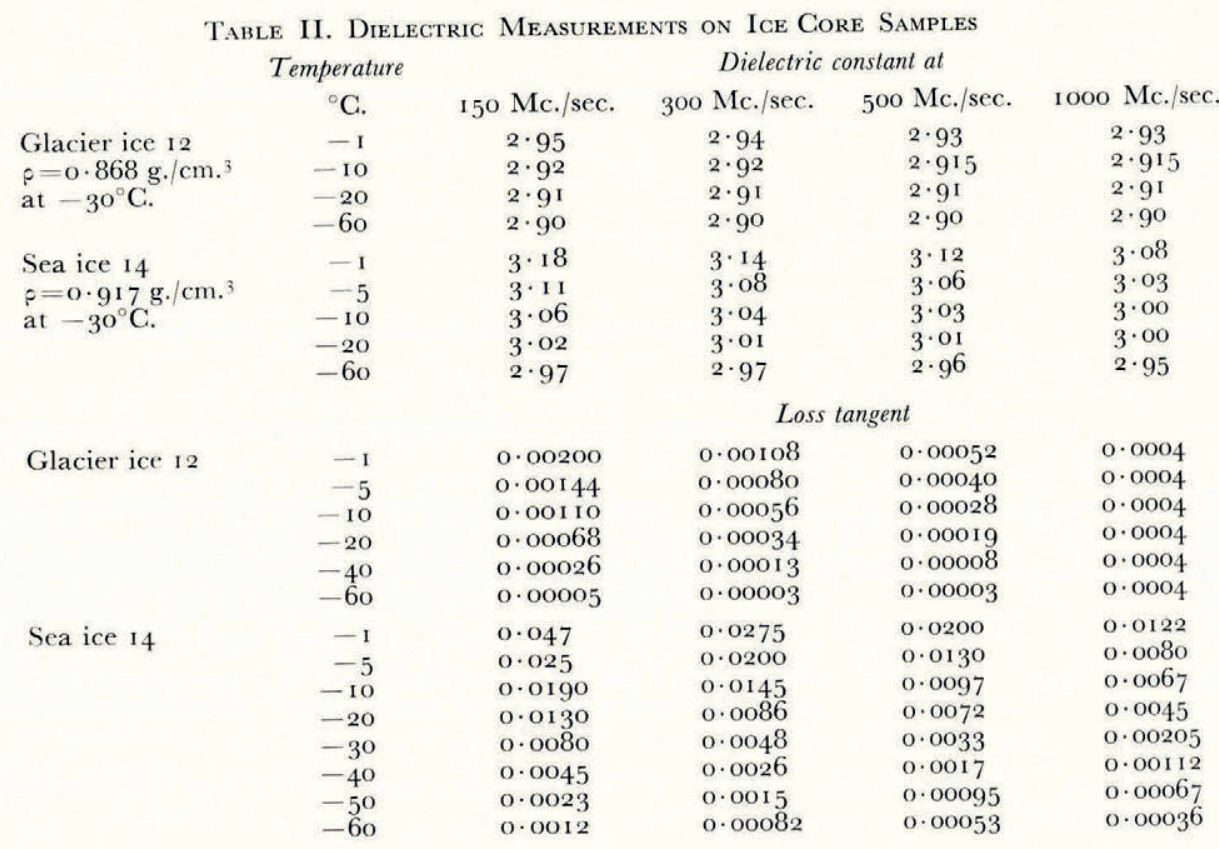

\section{Dielectric constant}

The dielectric properties of two ice samples, one from a glacier-ice zone and the other from a sea-ice zone, are listed in Table II. The measurements were made at a frequency range of $\mathrm{I}_{5} \mathrm{O}^{-\mathrm{I}}$, $000 \mathrm{Mc}$. $/ \mathrm{sec}$., and at temperatures ranging from $-\mathrm{I}^{\circ} \mathrm{C}$. to $-60^{\circ} \mathrm{C}$.

The dielectric data obtained from the two ice samples indicate a larger dielectric constant and larger loss tangent for the sea ice. The larger dielectric constant would be expected in view of the larger density of the sample, and the larger loss tangent would be expected in view of a greater percentage of conducting ions.

The dielectric data thus show a correlation with the other groups of parameters covered in this paper. The difference in dielectric constant suggests the possibility of detecting the glacier ice-sea ice interface by the reflections of electromagnetic waves. A quantitative discussion of such techniques, however, is beyond the scope of this paper.

\section{Acknowledgements}

We wish to acknowledge the following agencies and persons who provided help, support and assistance: Terrestrial Sciences Laboratory, Air Force Cambridge Research Laboratories; U.S. Naval Civil Engineering Laboratory; Dartmouth College; Defence Research Board, Canada. A. C. Smith, J. R. T. Molholm, F. G. Leavitt, and R. A. Lenton assisted in the field coring operations. 
We are especially indebted to J. B. Lyons, Dartmouth College, for his work on the ice rise core in the field and for his interest and suggestions in the laboratory. Thanks are expressed to H. Lister, Field Leader, and G. P. Rigsby, Principal Investigator of the I 960 Ward Hunt Project, for their suggestions and help, to W. B. Westphal, Massachusetts Institute of Technology, for measuring the dielectric values, and also to W. F. Weeks and R. C. Cameron for their suggestions and review of the manuscript.

MS. received 7 March 1963

\section{REFERENCES}

American Health Association, Inc. 1960. Standard methods for the examination of water and wastewater. Eleventh edition. Albany, N.Y., Boyd Printing Co., Inc.

Armstrong, T. E., and Roberts, B. B. I 956 . Illustrated ice glossary. Polar Record, Vol. 8, No. 52, p. 4-I 2.

Crary, A. P. 1958. Arctic ice island and ice shelf studies. Part I. Arctic, Vol. I I, No. I, p. 2-42.

Crary, A. P. 1960. Arctic ice island and ice shelf studies. Part II. Arctic, Vol. I 3, No. I, p. $32-50$.

Crowley, F. A. I96I. Density distribution for a two layer shelf. (In Rigsby, G. P., and Bushnell, V. C., ed. Proceedings of the third annual Arctic Planning Session, November 196o. Bedford, Mass., Geophysics Research Directorate, U.S. Air Force Cambridge Research Laboratories, p. 3i-33. (GRD Research Notes, No. 55.))

Hattersley-Smith, G., and others. I955. Northern Ellesmere Island, 1953 and I954, by G. Hattersley-Smith, [A. P. Crary and R. L. Christie]. Arctic, Vol. 8, No. 1, p. 3-36.

Hutchinson, G. E. 1957. A treatise on limnology. New York, John Wiley and Sons, Inc.

Knight, C. A. I962. Polygonization of aged sea ice. Fournal of Geology, Vol. 7o, No. 2, p. 240-46.

Langway, C. C., jr. 1958. Bubble pressures in Greenland glacier ice. Union Géodésique et Géophysique Internationale. Association Internationale d'Hydrologie. Scientifique. Symposium de Chamonix, I6-24 sept. 1958, p. 336-49.

Lyons, J. B., and Leavitt, F. G. I961. Structural-stratigraphic studies on the Ward Hunt Ice Shelf. GRD Air Force Cambridge Research Laboratories. Report $44^{2}$.

Lyons, J. B., and Ragle, R. H. I962. Thermal history and growth of the Ward Hunt Ice Shelf. Union Géodésique et Géophysique Internationale. Association Internationale d'Hydrologie Scientifique. Commission des Neiges et Glaces. Colloque d'Obergurgl, $10-9-18-9$ I962, p. 88-97. Marshall, E. W. 1955. Structure and stratigraphic studies of the northern Ellesmere ice shelf. Arctic, Vol. 8,
No. 2, p. Io9-14. Ragle, R. H. In press. The formation of lake ice in a tempcrate climate. U.S. Cold Regions Research and Engineering
Laboratory. Research Report 107. Schwarzacher, W. 1959. Pack-ice studies in the Arctic Ocean. Journal of Geophysical Research, Vol. 64, No. 12,
p. 2357-67.

Weeks, W. F., and Lee, O. S. 1962. The salinity distribution in young sea ice. Arctic, Vol, 15, No. 2, p. 92-108. 